\title{
Humeral Neck Fractures in Association with Traumatic Shoulder Dislocation
}

\author{
Sherif Mostafa Abdeldayem, Ahmed Nageeb Mahmoud and Ramy Ahmed Diab* \\ Orthopedic Surgery Department, Ain Shams University Hospitals, Egypt \\ Submission: December 20, 2017; Published: January 16, 2018 \\ *Corresponding author: Ramy Ahmed Diab, Department of Orthopedics, Ain Shams University, Cairo, Egypt, Tel: +201111243785; \\ Email: ramydiab79@gmail.com
}

\begin{abstract}
Aim: To evaluate the clinical and radiological outcomes of the open surgical management of concomitant neck humeral fractures and anterior glenohumeral dislocation with greater tuberosity fractures.

Materials and methods: Twenty eight anterior shoulder dislocations with greater tuberosity fracture in 28 patients were reviewed retrospectively. Out of them, 9 patients were found to have associated humeral neck fractures (OTA/AO 11-B3). Management of these patients consisted of open reduction and prophylactic fixation of the surgical neck fractures with proximal humeral plate.

Results: Radiographic analysis included fracture reduction, stability of the fixation construct, achievement of bony union and assessment of the femoral head avascular necrosis occurrence. Clinical outcomes were assessed by the shoulder range of motion, the presence of persistent shoulder pain and the occurrence of any post-operative complication that would necessitate intervention or deviation from the ordinary follow up. After a mean follow up of 19 months post-operative; all the patients achieved bony union of the fracture with good clinical outcomes. None of the cases developed humeral head avascular necrosis. Satisfactory clinical results have been obtained in all of the nine cases.

Conclusion: Early recognition of associated humeral neck fractures in patients with anterior shoulder dislocation and greater tuberosity fracture can minimize the incidence of iatrogenic fracture displacement. ORIF may offer a reasonable treatment option for such cases with lower incidence of complications.
\end{abstract}

Keywords: Proximal humerus fractures; Shoulder dislocation; Three part fractures; Fixation

\section{Introduction}

Association between anterior glenohumeral dislocation and greater tuberosity fractures has been reported in literature. Greater tuberosity fractures have been noted in as high as 10 $30 \%$ of shoulder dislocations [1]. Similarly, Bahrs et al. [2], found that over $50 \%$ of greater tuberosity fractures were associated with traumatic anterior glenohumeral dislocation in a review of over 100 patients. Infrequently reported, the presence of undisplaced humeral neck fracture with a two-part anterior fracture dislocation. These humeral neck fractures may be missed during the primary management, and presents a risk for displacement and conversion to three part fracture dislocation during un-experienced closed reduction [3,4].

We believe that the presence of humeral tuberosity fracture in association with shoulder dislocation should warren the surgeon to rule out an additional fracture through the neck humerus. We hypothesized that primary open reduction and internal fixation of such fractures with minimal soft tissue stripping during surgery may help in preserving the remaining blood supply to the humeral head and hence decreasing the incidence of AVN. In this report, we presented shortly a series of 9 cases of humeral neck fractures in association with anterior gleno humeral dislocation and greater tuberosity fracture (OTA 11-3B) that have been treated all with open reduction and internal fixation for the associated fractures with good results after a mean follow up of 19 months.

\section{Patients \& Methods}

We reviewed 28 cases of anterior gleno humeral dislocation with greater tuberosity fractures (OTA classification 11-B3) that have been presented to our trauma center. Pre reduction CT scans were routinely done for all patients with shoulder fracture dislocation in our institution. Out of the 28 cases, nine cases had associated humeral neck fracture ( 6 surgical, 3 anatomical) that were discovered with the pre reduction CT scans. Patients were 5 males and 4 females with a mean age of 52 years. All these patients underwent open reduction and internal fixation of the humeral neck and tuberosity fractures with proximal humeral locked plate. 


\section{Orthopedics and Rheumatology Open Access Journal}

The surgeries were done through the delto pectoral approach under general anesthesia and complete muscle relaxation. Surgery was done within 24-48 hours from presentation for all cases. Minimal soft tissue dissection was performed and no muscles were detached from the bony fragments during surgery. Prior to humeral head relocation, prophylactic $\mathrm{K}$ wire fixation was done to the humeral head and tuberosity fractures. The humeral head then is relocated under vision into the glenoid with gentle manipulation. Fixation was done using the proximal humeral locked plate.

\section{Results}

After a mean follow up of 19 months (range 14-27 months), all the patients achieved full radiological union of the proximal humeral fractures. No cases of humeral head avascular necrosis were recorded (Figure 1). One patient had post-operative surgical wound infection with continuous wound discharge and swelling and was treated with surgical debridement 3 weeks post-operative without further intervention. Two patients had occasional shoulder pain without functional limitation. Other complications of associated fractures were presented in Table 1.
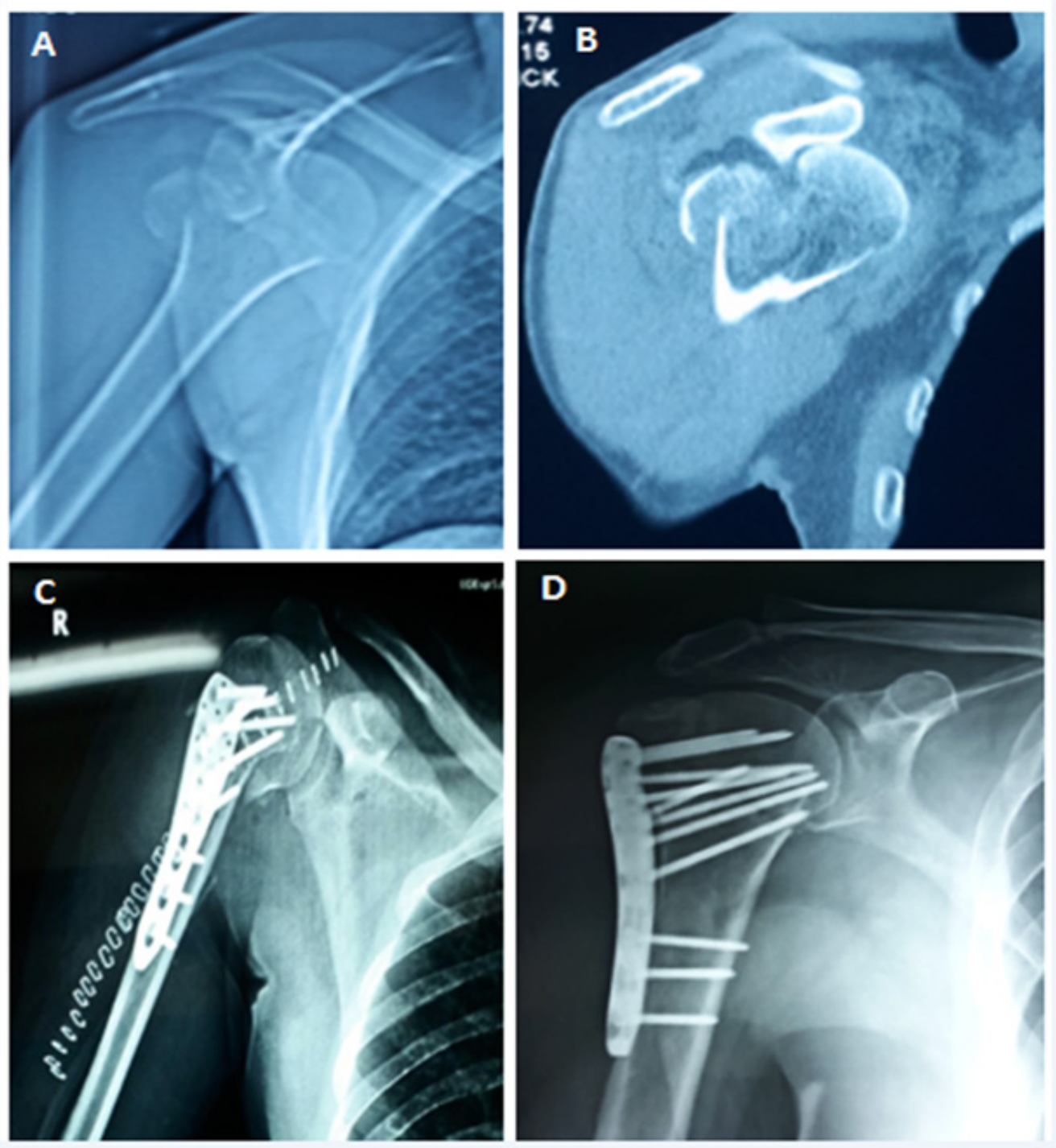

\section{Figure 1:}

A. Pre-operative plain shoulder radiograph showing anterior shoulder dislocation with greater tuberosity fracture with unseen humeral neck fracture.

B. Pre-operative CT scan showed an associated undisplaced humeral neck fracture.

C. Plain shoulder radiograph taken 1 day post operatively showing the stable fixation construct.

D. Plain shoulder radiograph taken 5 months post operatively showing the stable fixation construct, adequate bony union and absence of humeral head AVN. 
Table 1: Patient demographics and clinical data.

\begin{tabular}{|c|c|c|c|c|c|c|c|c|c|c|c|c|}
\hline \multirow{2}{*}{ Case } & \multirow{2}{*}{ Age } & \multirow{2}{*}{ Sex } & \multirow{2}{*}{$\begin{array}{l}\text { Mode of } \\
\text { trauma }\end{array}$} & \multirow{2}{*}{ Primary Injury } & \multirow{2}{*}{$\begin{array}{c}\text { Other } \\
\text { recognized } \\
\text { injury } \\
\text { after CT }\end{array}$} & \multirow{2}{*}{ Treatment } & \multirow{2}{*}{$\begin{array}{c}\text { Follow } \\
\text { up }\end{array}$} & \multicolumn{4}{|c|}{$\begin{array}{l}\text { Shoulder ROM at } \\
\text { last follow up. }\end{array}$} & \multirow{2}{*}{ Complications } \\
\hline & & & & & & & & $\mathbf{F}$ & $\mathbf{E}$ & $\mathbf{R}$ & ABD & \\
\hline 1 & 39 & M & MVA & $\begin{array}{l}\text { Anterior shoulder } \\
\text { dislocation } \\
\text { + Greater } \\
\text { tuberosity } \\
\text { fracture; Open } \\
\text { fracture Both } \\
\text { bones leg }\end{array}$ & $\begin{array}{l}\text { Surgical } \\
\text { neck } \\
\text { Humerus }\end{array}$ & $\begin{array}{c}\text { ORIF with } \\
\text { proximal humeral } \\
\text { locked plate } \\
\text { for Shoulder; } \\
\text { External fixation } \\
\text { for tibia followed } \\
\text { by ORIF after } 2 \\
\text { weeks. }\end{array}$ & 17 & 130 & 40 & 80 & 90 & None \\
\hline 2 & 59 & $\mathrm{~F}$ & $\begin{array}{l}\text { Direct } \\
\text { Fall }\end{array}$ & $\begin{array}{l}\text { Anterior shoulder } \\
\text { dislocation } \\
+ \text { Greater } \\
\text { tuberosity } \\
\text { fracture }\end{array}$ & $\begin{array}{l}\text { Anatomical } \\
\text { neck } \\
\text { fracture }\end{array}$ & $\begin{array}{l}\text { ORIF with } \\
\text { proximal humeral } \\
\text { locked plate }\end{array}$ & 14 & 90 & 40 & 60 & 70 & $\begin{array}{l}\text { Wound infection, } \\
\text { treated with } \\
\text { debridement }\end{array}$ \\
\hline 3 & 64 & $\mathrm{~F}$ & $\begin{array}{l}\text { Fall on } \\
\text { Out- } \\
\text { stretched } \\
\text { hand }\end{array}$ & $\begin{array}{l}\text { Anterior shoulder } \\
\text { dislocation } \\
+ \text { Greater } \\
\text { tuberosity } \\
\text { fracture }\end{array}$ & $\begin{array}{l}\text { Anatomical } \\
\text { neck } \\
\text { fracture }\end{array}$ & $\begin{array}{l}\text { ORIF with } \\
\text { proximal humeral } \\
\text { locked plate }\end{array}$ & 23 & 90 & 50 & 50 & 80 & $\begin{array}{l}\text { Occasional shoulder } \\
\text { pain without } \\
\text { functional limitation. }\end{array}$ \\
\hline 4 & 48 & M & $\begin{array}{c}\text { Fell from } \\
\text { height }\end{array}$ & $\begin{array}{l}\text { Anterior shoulder } \\
\text { dislocation } \\
+ \text { Greater } \\
\text { tuberosity } \\
\text { fracture+ Fracture } \\
\text { Shaft femur }\end{array}$ & $\begin{array}{l}\text { Surgical } \\
\text { neck } \\
\text { fracture }\end{array}$ & $\begin{array}{l}\text { ORIF with } \\
\text { proximal humeral } \\
\text { locked plate } \\
\text { for shoulder; } \\
\text { Interlocking nail } \\
\text { femur. }\end{array}$ & 18 & 105 & 30 & 70 & 90 & $\begin{array}{l}\text { Femur non union, } \\
\text { treated with } \\
\text { dynamization and } \\
\text { bone grafting. }\end{array}$ \\
\hline 5 & 49 & $\mathrm{~F}$ & Direct fall & $\begin{array}{l}\text { Anterior shoulder } \\
\text { dislocation } \\
+ \text { Greater } \\
\text { tuberosity } \\
\text { fracture }\end{array}$ & $\begin{array}{l}\text { Surgical } \\
\text { neck } \\
\text { fracture }\end{array}$ & $\begin{array}{l}\text { ORIF with } \\
\text { proximal humeral } \\
\text { locked plate }\end{array}$ & 17 & 110 & 40 & 80 & 100 & $\begin{array}{l}\text { Occasional shoulder } \\
\text { pain without } \\
\text { functional limitation. }\end{array}$ \\
\hline 6 & 28 & M & MVA & $\begin{array}{l}\text { Anterior shoulder } \\
\text { dislocation } \\
\text { + Greater } \\
\text { tuberosity } \\
\text { fracture; } \\
\text { Bimalleolar ankle } \\
\text { fracture }\end{array}$ & $\begin{array}{l}\text { Anatomical } \\
\text { neck } \\
\text { fracture }\end{array}$ & $\begin{array}{l}\text { ORIF with } \\
\text { proximal humeral } \\
\text { locked plate for } \\
\text { shoulder; ORIF } \\
\text { for ankle. }\end{array}$ & 25 & 130 & 50 & 90 & 120 & None. \\
\hline 7 & 57 & M & Direct fall & $\begin{array}{l}\text { Anterior shoulder } \\
\text { dislocation } \\
\text { + Greater } \\
\text { tuberosity } \\
\text { fracture }\end{array}$ & $\begin{array}{l}\text { Surgical } \\
\text { neck } \\
\text { fracture }\end{array}$ & $\begin{array}{l}\text { ORIF with } \\
\text { proximal humeral } \\
\text { locked plate. }\end{array}$ & 14 & 100 & 20 & 60 & 80 & $\begin{array}{l}\text { Delayed union for } \\
\text { greater tuberosity (8 } \\
\text { months). }\end{array}$ \\
\hline 8 & 63 & M & Direct fall & $\begin{array}{l}\text { Anterior shoulder } \\
\text { dislocation } \\
+ \text { Greater } \\
\text { tuberosity } \\
\text { fracture }\end{array}$ & $\begin{array}{l}\text { Surgical } \\
\text { neck } \\
\text { fracture }\end{array}$ & $\begin{array}{l}\text { ORIF with } \\
\text { proximal humeral } \\
\text { locked plate }\end{array}$ & 16 & 90 & 10 & 60 & 50 & None. \\
\hline 9 & 61 & $\mathrm{~F}$ & Direct fall & $\begin{array}{l}\text { Anterior shoulder } \\
\text { dislocation } \\
+ \text { Greater } \\
\text { tuberosity } \\
\text { fracture }\end{array}$ & $\begin{array}{l}\text { Surgical } \\
\text { neck } \\
\text { fracture }\end{array}$ & $\begin{array}{l}\text { ORIF with } \\
\text { proximal humeral } \\
\text { locked plate }\end{array}$ & 27 & 90 & 20 & 70 & 80 & $\begin{array}{l}\text { Delayed union for } \\
\text { greater tuberosity ( } 9 \\
\text { months) }\end{array}$ \\
\hline
\end{tabular}

\section{Discussion}

In this retrospective study, we present nine cases of anterior three part gleno-humeral fracture dislocation, in which an associated humeral neck fracture was present and confirmed early in the shoulder CT scan prior to any attempt for shoulder reduction. All cases were treated by open reduction and internal fixation and none of them developed humeral head AVN after a mean follow up of 19 months post-operative. 
Iatrogenic humeral neck fracture displacement was reported with closed reduction of shoulder dislocation and humeral tuberosity fractures [3-5]. Hersche \& Gerber [4] reported about seven cases of humeral neck fractures with 2 part anterior shoulder dislocation and six of them were treated primarily with closed reduction in which avascular necrosis has been developed in five of them. One case has been diagnosed using repeated shoulder radiographs and open reduction was tried primarily with later development of humeral head AVN too.

The authors recommended proper assessment of all cases of greater tuberosity fracture dislocation of the shoulder before any trial for closed reduction, for the presence of any associated neck fracture. Similarly, Ferkel et al. [3] reported about two cases of primarily un recognized humeral neck fracture in association with anterior shoulder fracture dislocation, that was iatrogenically displaced with forceful trial of closed reduction. The two patients underwent ORIF later with fair clinical outcomes, although one case developed partial AVN of the humeral head. De Mourgoues et al. [5] also reported about two cases of humeral neck displacement with closed reduction for the shoulder dislocation. Razemon \& Baux [6], who reviewed 1415 fractures and fracture-dislocations of the proximal humerus, concluded that iatrogenic displacement of a neck fracture could rarely occur in association with fracture dislocations of the greater tuberosity.

In the two studies that were primarily concerned with this type of injury, the incidence of humeral head AVN ranged 50$85 \%[3,4]$. In the majority of cases that developed AVN in the two studies ( 8 out of nine cases), seven of them have been managed primarily with a gentle or forceful attempt of closed reduction, and only one case has AVN after primary ORIF. We hypothesized that primary open reduction and internal fixation of such fractures with minimal soft tissue stripping during surgery may help in preserving the remaining blood supply to the humeral head and hence decreasing the incidence of AVN. The results of our series may support this hypothesis; however more studies are needed with larger number of patients and with a prospective, randomized nature would be definitely needed to reach a more clinically significant conclusion.

The presence of associated greater or lesser tuberosity fracture was constantly mentioned in all of the previous reports about this injury [3-5], as well as in our series. We believe that the presence of humeral tuberosity fracture in association with shoulder dislocation should warren the surgeon to rule out an additional fracture through the neck humerus. Adequate radiographic assessment should be performed before any reduction of the shoulder is attempted. In our institution, CT scan is done routinely for all cases of shoulder fracture dislocation. Interestingly, we found that the size of greater tuberosity fracture may be correlated with the presence of associated humeral neck fracture. In our series of 28 cases, the nine cases of associated neck fracture had a fragment size of $>25 \%$ of the head size.
There is much controversy about the choice of treatment of three part fracture dislocation injuries of the shoulder. Myles recommended closed manipulation because the results of surgery were unpredictable [7]. Neer recommended open reduction and internal fixation for treatment of anterior fracture dislocation [8]. Silverskiold studied 80 fracture dislocation cases treated by manipulation with only $45 \%$ success and advised that all such injuries should be openly reduced [9]. Ferkel et al. [3] stated that in their treatment algorithm for managing acute fracture dislocations of the shoulder that if the x-ray revealed a non-displaced humeral neck fracture associated with the two part fracture dislocation. They stated that closed reduction should be tried under GA using fluoroscopic control first, and ORIF should be done if subsequent displacement occurs. Ferkel et al. [3] recommended ORIF for all 3 part displaced fracture dislocation. We agree partially with Ferkel et al, although we recommend immediate ORIF if any undisplaced humeral neck fracture was discovered prior to any attempt for closed reduction.

So our recommendations in the treatment of these types of two-part greater tuberosity anterior fracture dislocation shoulder include:

i. CT scan should be done routinely in all cases before any manipulation.

ii. Associated neck fracture must always be ruled out; especially where there is greater tuberosity with a fragment size $>25 \%$ of the head size.

iii. If a humeral neck fracture is discovered in association with anterior gleno humeral dislocation and greater tuberosity fracture, ORIF may offer a reasonable treatment, even if nondisplaced to prevent the incidence of catastrophic iatrogenic fracture displacement during closed reduction and to minimize the incidence of later development of humeral head AVN.

This study has many inherent limitations. First, being retrospective study with lower level of evidence. The very few number of patients also is considered a major limitation that could question the evidence and clinical value of the study. Also, selection of the management procedure depended on the surgeons' own decision which creates a considerable degree of bias. Although the fact that this fracture pattern is relatively rare and the available literature describing it are scarce, which could present some clinical value to the current study, a prospective, randomized controlled study with higher cases number should provide much more clinical and scientific evidence.

\section{Conclusion}

A high index of suspicion should be present in all patients with greater tuberosity fracture dislocation for the presence of associated humeral neck fracture. Adequate pre-operative radiographic assessment by CT scan should be done before any attempt for closed reduction to avoid disastrous complications 
of fracture displacement. ORIF may be a reasonable treatment option for such cases with good clinical and radiographic outcomes.

\section{Conflict of Interest}

The authors declare that there are no conflicts of interest that are related to this work.

\section{References}

1. Gruson KI, Ruchelsman DE, Tejwani NC (2008) Isolated tuberosity fractures of the proximal humeral: current concepts. Injury 39(3): 284-298.

2. Bahrs C, Lingenfelter E, Fischer F, Walters EM, Schnabel M (2006) Mechanism of injury and morphology of the greater tuberosity fracture. J Shoulder Elbow Surg 15(2): 140-147.

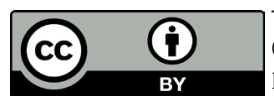

This work is licensed under Creative Commons Attribution 4.0 License

DOI: 10.19080/OROAJ.2018.10.555779
3. Ferkel RD, Hedley AK, Eckardt JJ (1984) Anterior fracture -disloctions of the shoulder: pitfalls in treatment. J Trauma 24: 363-367.

4. Hersche O, Geber C (1994) Iatrogenic displacement of fracturedislocations of the shoulder. JBJS (Br) 76(1): 30-33.

5. De Mourgues G, Razemon JP, Leclair HP (1965) Les fractures -luxations de le epaule. Rev Chir.

6. Razeemon JP, BauxS (1969) Les fractures et les fractures-luxations de le extremitesuperieure de la humerus. Rev Chir Orthop 55: 387-496.

7. Myles JW (1972) Manipulative reduction of fracture- dislocation of the shoulder. Proc Roy Soc Med 65: 1033-1034.

8. Roockwood CA Jr, Green DP (1972) Fractures. Philadelphia, Lippincott, USA, pp. 585-610.

9. Silverskiold N (1928) On the treatment of fracture- dislocations of the shoulder -joint. Acta Chir Scand 64: 227-293.

\section{Your next submission with Juniper Publishers will reach you the below assets}

- Quality Editorial service

- Swift Peer Review

- Reprints availability

- E-prints Service

- Manuscript Podcast for convenient understanding

- Global attainment for your research

- Manuscript accessibility in different formats

( Pdf, E-pub, Full Text, Audio)

- Unceasing customer service

Track the below URL for one-step submission

https://juniperpublishers.com/online-submission.php 